\title{
超高強度繊維補強コンクリートを用いた プレストレストスラブの耐火設計および施工
}

\author{
馬場重彰*1・笹井弘雄*2 ・森田 尚*3 ・ 野崎浩司*1
}

\begin{abstract}
概 要 本報告では, 超高強度緎維補強コンクリートを用いたプレストレストスラブの耐火性能を記述する。載荷加熱 試験を実施した結果, 緊張材の高温時特性を評価・把握することで, 而火時間を推定できることが分かった。さらに, プ レストレストスラブを建築構造物に適用し，その概要を述べる。 キーワード：超高強度繊維補強コンクリート，プレストレス，スラブ，而火設計
\end{abstract}

\section{1.はじめに}

無機系複合材料在用いた圧縮強度が $200 \mathrm{~N} / \mathrm{mm}^{2}$ 級の 超高強度繊維補強コンクリート（以下，UFC と表記す る。UFC : Ultra-High Strength Fiber Reinforced Concrete）は，その設計法扮よび施工法の研究・開発 が精力的に進められてきた口。実構造物へは主に土木構 造物への採用が図られ，2002 年に竣工した「酒田みら (橋」2)（写真-1）をはじめ，「赤倉温泉ゆけむり橋」（写 真-2）など多数存在する。

UFC 材料は，従来のコンクリートに比べて極めて高 い压縮強度を有するだけでなく，じん性と耐久性にも富 む，高性能な新素材である。このような高い性能を持つ 新素材をプレストレストコンクリート部材などに適用す ることにより，構造部材のスリム化が可能になるととも に，建物の大スパン化・大空間化が可能となる ${ }^{32}$ 。

UFC 材料は高緻密・高強度であり爆裂が懸念される が文，有機繊維を混入してその耐火性能を向上させている。

一方，プレストレストコンクリート部材は，火災時に 爆裂を生じやすいことが指摘されており，緻密で而火対 策が必要な UFC 材料を適用するにあたっては，十分な 検討が必要である ${ }^{4) 5}$ )。日本建築学会「プレストレスト 部材の設計・施工指針 $\rfloor^{6)}$ (以下， PC 規準）では，プレ ストレストコンクリートの耐火性が付録に掲載されてお り，而火性能を確保するためには耐火時間により $\mathrm{PC}$ 鋼 棒のかぶり量を示している。プレストレストコンクリー 卜部材の火災時曲げ耐力評価を解析的に検討したものに 文献 7) があり，PC替準に示されている PC 鋼材かぶり 厚さの妥当性を検討している。

そこで筆者らは，耐火性能を改善したUFC 材料在用

*1ばば・しげあき/大成建設街 技術センター 建築技術研究所 課 長代理（正会員）

*2 ささい・ひろお/大成建設㑣) 設計本部 構造グルーフ

*3 もりた・たかし 大成建設㑣 技術センター 技術企画部 課長

*4のざき・ひろし/大成建設㑣 横浜支店 作業所長

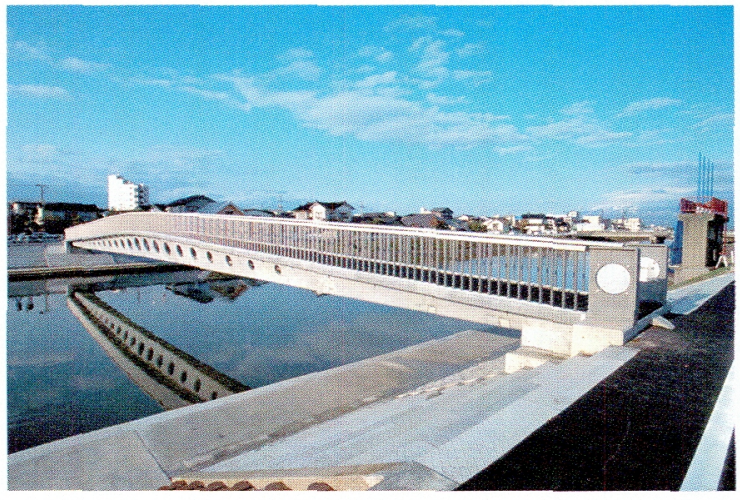

写真-1＼cjkstart酒田みらい橋

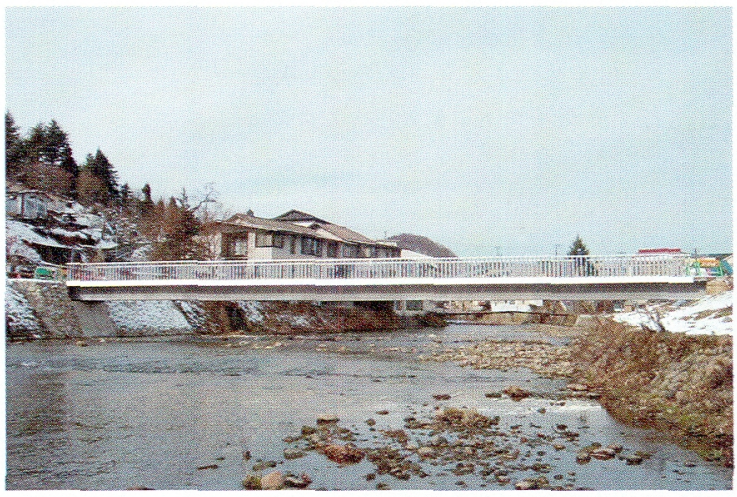

写真-2＼cjkstart赤倉温泉ゆけむり橋

いたプレストレストスラブ（以下，UFCスラブ）につ いて，実験にもとづく耐火性能の検証，耐火設計の考え 方を検討した。また，製造方法などの検討も行い，実際 の建物への適用を行った。

2. 而火火性能および而火設計手法

\section{1 使用した UFC 材料の特徵}

使用したUFC はセメント，シリカ質混和材，骨材， 水，減水剂拈よび補強用鋼繊維（文献 1) で記述）に爆 裂対策用の有機䋊維を組合せたもので，粗骨材を含まな い。フレッシュコンクリートの性能は，JIS R $5210 「 セ ~$ メントの物理試験方法」に準拠したモルタルフロー（フ 


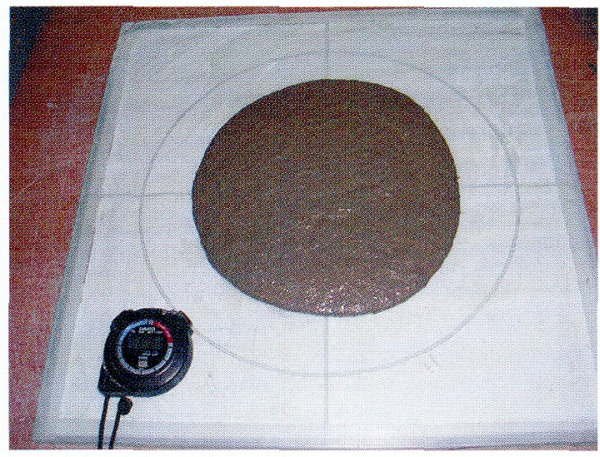

写真-3 モルタルフロー状況

ローテーブルの落下運動はしない）によって確認するこ ととしている。写真-3に示すように，モルダルフロー は扮扮む称 $200 \mathrm{~mm}$ 程度であり，施工性も良好である。 また，打設後，常温養生の後，最高 $90^{\circ} \mathrm{C}$ (48 時間) の 蒸気養生老行うことで, 圧縮強度 $200 \mathrm{~N} / \mathrm{mm}^{2}$ 程度を得 ることができる1。

压縮強度之各種強度の関係を図-1〜図-3に示す。試 験は，材齢１日，6日，10日（蒸気養生後）にて実施し た。各材齢時での各種強度は，供試体 3 本の平均である。 試験方法は，いずれあコンクリートのJIS 規格（JIS A 1108 「ンクリートの压縮強度試験方法」, JIS A 1106 「コンクリートの曲げ強度試験方法」, JIS A 1113 「コ ンクリートの割裂引張強度試験方法」）に準拠して実施 している。ただし，繊維補強コンクリートであるため， 割裂引張強度試験では供試体の割裂以降屯強度が緩やか に増加する。そこで，ここでは，供試体の端面にひずみ ゲージを貼り，供試体のひずみ值が急激に变化した時を 割裂引張ひび割れ強度，最大荷重となった時を割裂引張 強度上定義した。また，薄肉部材の構造体コンクリート では，JIS A 1108 で記述されている径 $100 \mathrm{~mm}$ 以上の コア供試体が採取できないことから，径 $50 \mathrm{~mm}$ と径 $100 \mathrm{~mm}$ で同等の強度を確認した。网-1〜図-3より， 全ての関係において，圧縮強度が増大するにつれ，各種 強度む増加していることが分かる。

\section{2 而火試験体}

高強度コンクリートを用いたプレストレスト構造では,

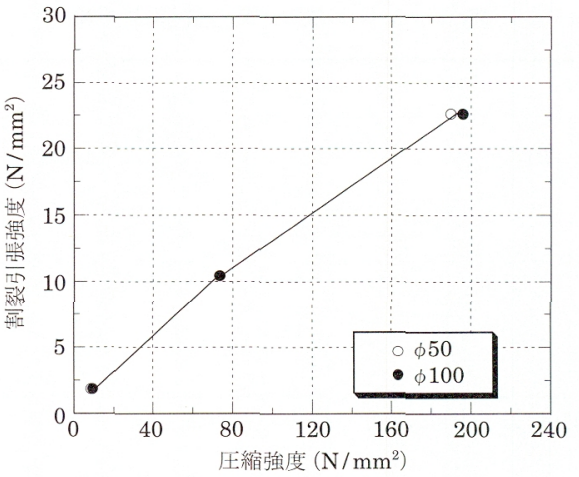

図-1＼cjkstart圧縮強度と曲げ強度の関係

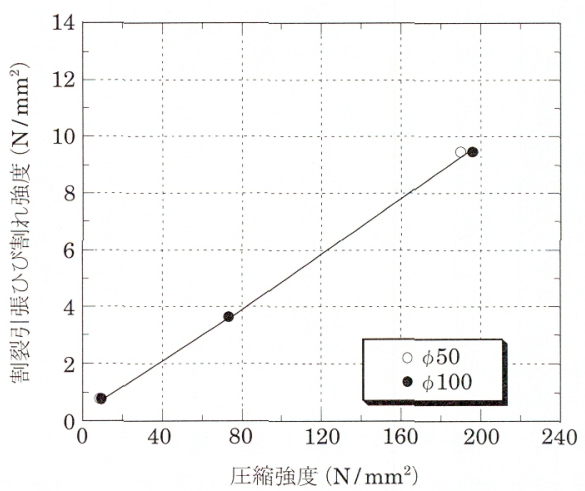

図-2＼cjkstart圧縮強度と割裂引張ひび割れ強度の関係

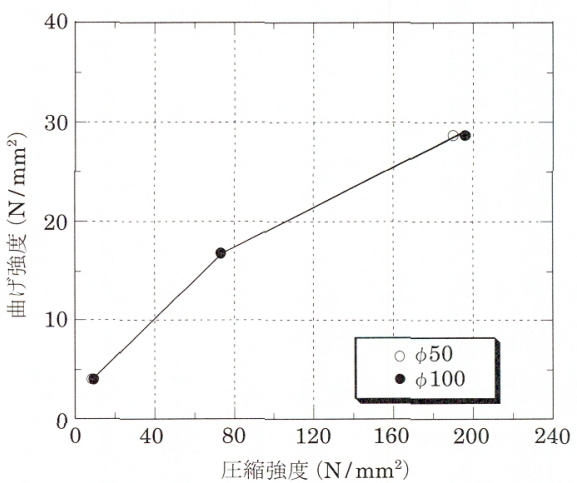

図-3＼cjkstart圧縮強度と割裂引張強度の関係

導入応力が存在すること, 部材厚が小さいことなどから 火災時に爆裂の危険性が指摘されている ${ }^{4)}$.5)。そこで, UFC スラブの耐火性能を把握するために, 載荷加熱試 験を実施した。また，プレストレスト構造の耐火性能を

Fire Resistance Design and Construction of Prestressed Slab with Ultra-High Strength Fiber Reinforced Concrete

By S. Baba, H. Sasai, T. Morita and H. Nozaki

Concrete Journal, Vol.45, No.7, pp.38 45, Jul. 2007

Synopsis The paper first summarizes the findings from loaded heating tests of prestressed slabs made of ultra-high strength fiber reinforced concrete (UFC). Based on the test results, a design procedure was developed for estimating the fire resistance of UFC slabs, taking into account the temperature rise and loss of strength of prestressing steel, both induced by heating during fires. Furthermore, the report provides a brief overview on the process of fabrication and installation of the UFC slabs for the enlargement and refurbishment project of an existing office building in Yokohama, Japan.

Keywords : ultra-high strength fiber reinforced concrete, pre-stress, slab, fire resistance design 
表-1シリーズA での試験体一覽

\begin{tabular}{|c|c|c|c|c|c|c|}
\hline 武験体名 & 加熱方法 & $\begin{array}{l}\text { 渞 入 } \\
\text { 緊張力 }\end{array}$ & $\begin{array}{c}\text { 中央位置 } \\
\text { での作用 } \\
\text { モーメント } \\
M\end{array}$ & $\begin{array}{c}\text { 耐力*1 } \\
\text { (計算·值) } \\
M u\end{array}$ & \multirow[t]{2}{*}{$M / M u$} & 生縮強度 \\
\hline & & $\mathrm{kN}$ & $\mathrm{kN} \times \mathrm{m}$ & $\mathrm{kN} \times \mathrm{m}$ & & $\mathrm{N} / \mathrm{mm}^{2}$ \\
\hline A-1 & \multirow[t]{3}{*}{ 仙面 } & \multirow[t]{3}{*}{672} & 26.2 & \multirow[t]{3}{*}{42.6} & 0.61 & 197 \\
\hline$A-2$ & & & 18.5 & & 0.43 & 187 \\
\hline A-3 & & & 13.1 & & 0.31 & 202 \\
\hline
\end{tabular}

表-2 シリーズBでの試験体一覧

\begin{tabular}{|c|c|c|c|c|c|c|}
\hline \multirow[t]{2}{*}{ 試験体名 } & \multirow[t]{2}{*}{ 加熱万法 } & $\begin{array}{l}\text { 導 入 } \\
\text { 緊張力 }\end{array}$ & $\begin{array}{c}\text { 中央位置 } \\
\text { での作用 } \\
\text { モーメント } \\
M\end{array}$ & $\begin{array}{c}\text { 耐力*1 } \\
\text { (計算值) } \\
M u\end{array}$ & \multirow[t]{2}{*}{$M / M u$} & 压縮強度 \\
\hline & & $\mathrm{kN}$ & $\mathrm{kN} \times \mathrm{m}$ & $\mathrm{kN} \times \mathrm{m}$ & & $\mathrm{N} / \mathrm{mm}^{2}$ \\
\hline B-1 & 両面 & \multirow[t]{3}{*}{567} & 24.3 & \multirow[t]{3}{*}{89.9} & 0.27 & 195 \\
\hline B-2 & \multirow[t]{3}{*}{ 片面 } & & 24.3 & & 0.27 & 176 \\
\hline$B-3$ & & & 39.3 & & 0.43 & 179 \\
\hline B-4 & & 987 & 42.6 & 158.0 & 0.27 & 179 \\
\hline
\end{tabular}

表-3 PC 鋼より線の材料特性

\begin{tabular}{|c|c|c|c|c|c|}
\hline \multirow[t]{2}{*}{ 試験体名 } & \multirow{2}{*}{$\begin{array}{l}\mathrm{PC} \text { 鋼 } \\
\text { より線 } \\
\text { 仕 様 }\end{array}$} & $\begin{array}{c}\text { 降伏強度 } \\
\sigma_{y}\end{array}$ & $\begin{array}{c}\text { 引張強度 } \\
\sigma_{t}\end{array}$ & 伸 び & 弾性係数 \\
\hline & & $\mathrm{N} / \mathrm{mm}^{2}$ & $\mathrm{~N} / \mathrm{mm}^{2}$ & $\%$ & $\mathrm{kN} / \mathrm{mm}^{2}$ \\
\hline $\begin{array}{l}\mathrm{A}-1 \sim \mathrm{A}-3 \\
\mathrm{~B}-1 \sim \mathrm{B}-3\end{array}$ & $\begin{array}{l}\text { 7本より } \\
15.2 \mathrm{~mm}\end{array}$ & 1896 & 1997 & 7.1 & 191 \\
\hline$B-4$ & $\begin{array}{l}19 \text { 本より } \\
19.3 \mathrm{~mm}\end{array}$ & 1858 & 1961 & 6.2 & 191 \\
\hline
\end{tabular}

明らかにするとと屯に，高温時曲げ耐力の推定および耐 火設計手法に関しても検討在行った。

試験体一覧を表-1〜表-2に示す。また，PC鋼より線 の材料特性を表-3 に示す。試験では2 シリーズ実施し た。試験体形状は 2 シリーズともに, 支点間距離約 $3600 \mathrm{~mm}$ ，試験体長 $4200 \mathrm{~mm}$ ，幅 $1500 \mathrm{~mm}$ とした。

(1)シリーズ A

まず，プレストレスト構造の耐火実験がほとんど存在 しないことからシリーズ A ではその基礎性能の把握 を目的として，厚さ $90 \mathrm{~mm}$ の平板に拈いて載荷荷重を 了段階として載荷加熱試験走実施した。試験体断面を 図-4（a）に示す。

(2)シリーズB

任意断面での耐火性能を検討するため, 図-4 (b), (c) に示す 3 リブ断面形状（リブ厚は $250 \mathrm{~mm}$ おょび 170 $\mathrm{mm}$ ，一般部で $70 \mathrm{~mm}$ ) でのプレストレストスラブの 載荷加熱試験を実施した。試験变数は,

1）加熱方法

片面 (下面) 加熱または而面（上下面）加熱

2）導入緊張力

3）載荷荷車

とした。試験体数は計 4 体である。

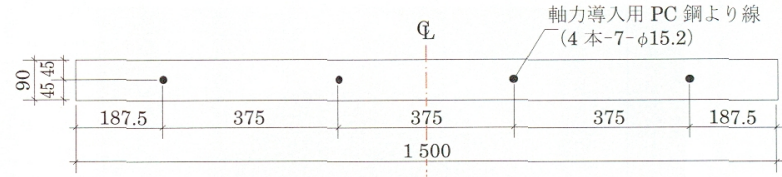

（a）シリーズ $\mathrm{A}$ 試験体断面

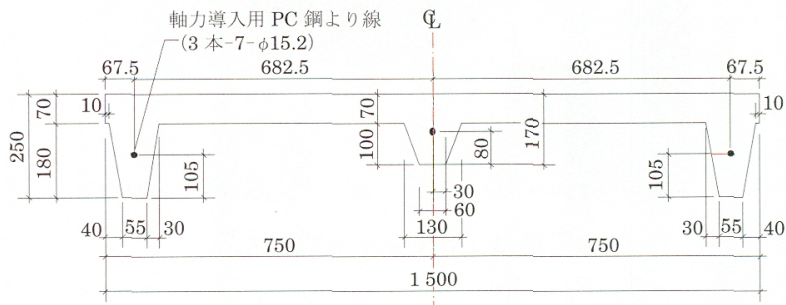

(b) $\mathrm{B}-1 \sim \mathrm{B}-3$ 試験体断面

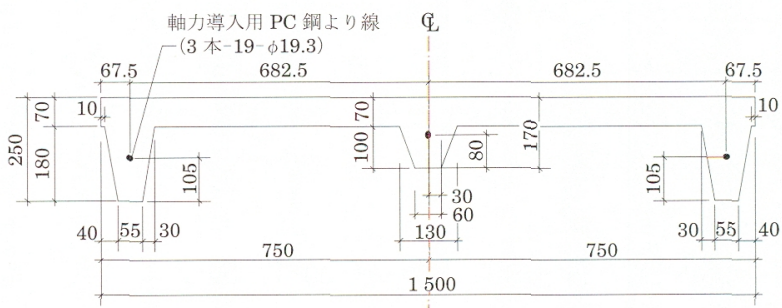

(c) B-4 試験体断面

図-4 試験体

\section{3 載荷加熱試験のセットアップ}

片面 (下面) 执よび画面（上下面）加熱のセットアッ プを図-5〜図-6に示す。本報に扮いて，闿面（上下面） 加熱老基本とした。これはアアトリウムなどの吹抜け空 間に架ける梁やスラブは，火災継続中，画面から火災を 要けると考えられるためである。加力方法は，支点間距 離在約 $3600 \mathrm{~mm}$ （支持条件は片側ピン，片側ピンロー ラ一)，載荷位置支支点加ら $900 \mathrm{~mm}$ 位置とし，4点曲 げとした。

載荷加熱試験中，試験体中央位置の变位量および支点 位置の变位量走变位計によって測定した。両面（上下面）

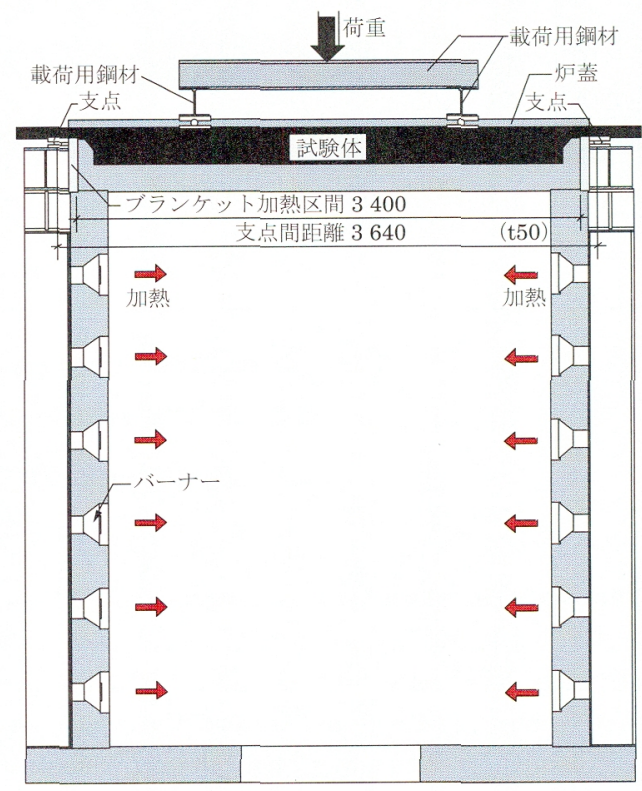

図-5 片面 (下面) 加熱のセットアップ 


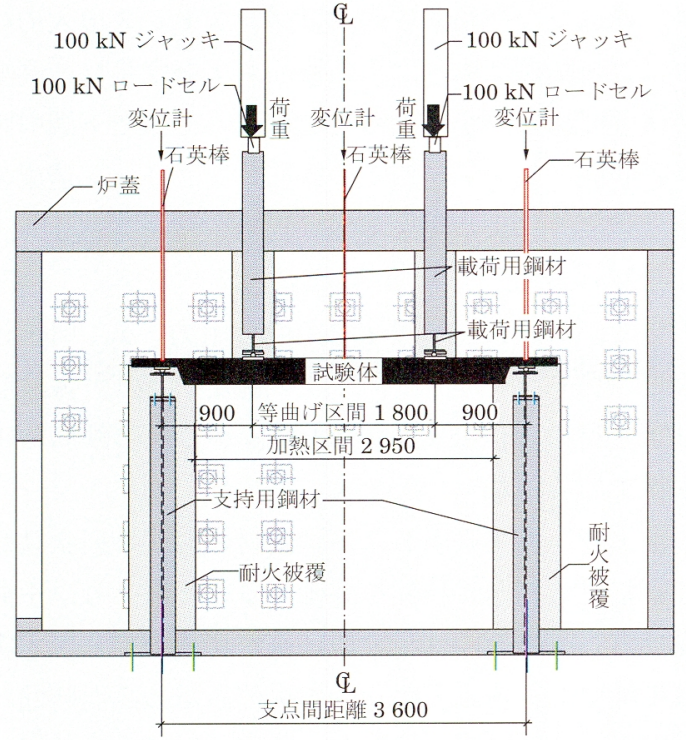

図-6 両面（上下面）加熱のセットアップ

加熱での測定には石英棒を炉内に挿入し，図-6に示す ように石英棒を介して变位量の測定を行った。試験体中 央位置のたわみ量は，試験体中央位置での変位量から支 点位置での变位量を差し引くことにより算出した。加熱 温度曲線は ISO-834 $4^{8)}$ に準拠した。

\section{4 載荷加熱試験結果}

各試験体とも，表層のごく一部に剥離が認められた屯 ののその形状を保持していた（写真-4）。

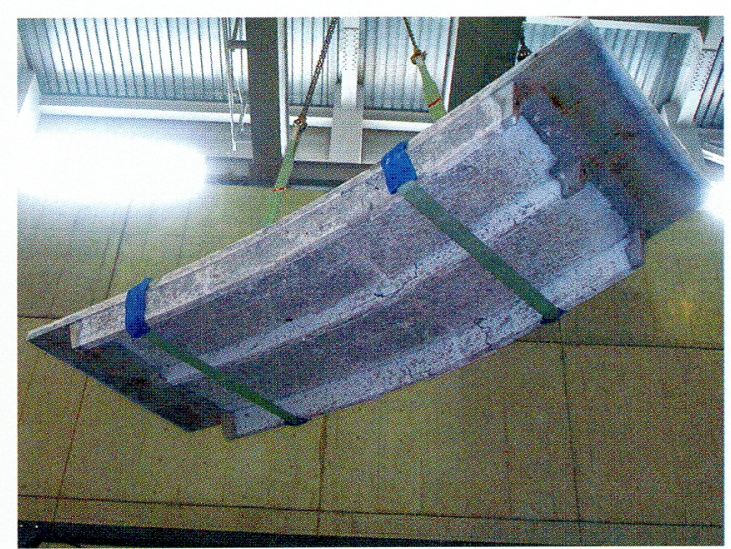

写真-4＼cjkstart実験後の状況（B-1 試験体）

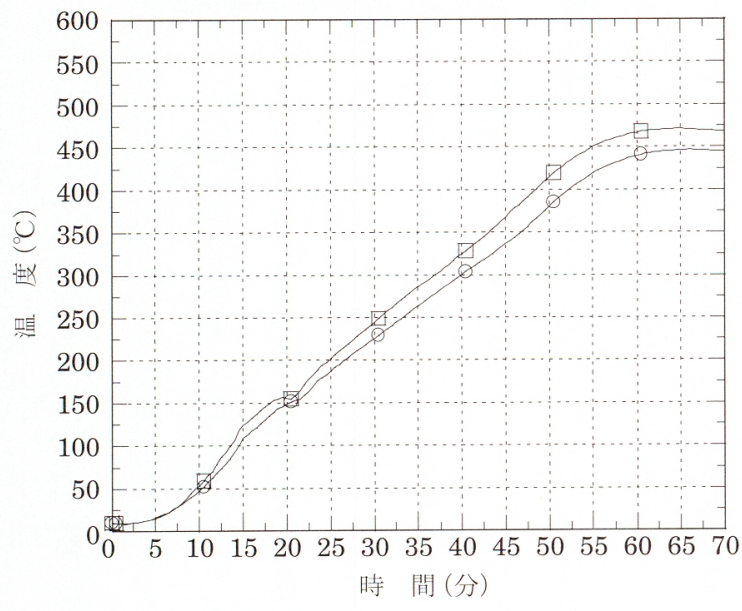

図-7 緊張材の温度測定結果 (A-1 試験体)
緊張材温度測定結果の一例（A-1 試験体）を図-7に 示す。加熱後 5 分までは温度はほとんど上昇しないが， 5 分以降急激に温度が上昇し, 20 分で約 $150^{\circ} \mathrm{C}, 60$ 分 で約 $450^{\circ} \mathrm{C}$ となった。

試験体中央位置でのたわみ量在-8〜図-10 に示す。 図-8 ではシリーズ $\mathrm{A}$ 試験体での載荷荷重の相違を, 図9 ではシリーズ B 試験体での加熱方法による相違を, 図-10 ではシリーズ B 試験体での緊張力・緊張材による 相違をそれぞれ示している。

たわみの加熱後の傾向を以下に示す。全試験体におい て，加熱当初は試験体内での温度差（温度勾配）により たわみ量が急激に進んだ。加熱当初の温度差による熱变 形は片面加熱の加大きかった。その後, 温度差が徐々 に緩やかになるとともにたわ子量の進行具合が遅くなっ た。そして温度の上昇とともに部材の曲げ剛性が低下し てたわみ量が大きくなり, 最終的にはたわみ量が急激に 増加して部材の荷重支持能力を失った。

載荷荷重に関しては, 図-8に示すように, 載荷荷重 が大きいほよ゙たわみの進行が早く，また載荷荷重が大き いほど少ないたわみ量で崩壊に至った。

加熱方法に関しては, 网-9に示すように, 加熱当初 のたわみは温度勾配が大きくなる片面加熱の方が大きい 屯のの, その後, 両面加熱試験体での断面内温度が片面

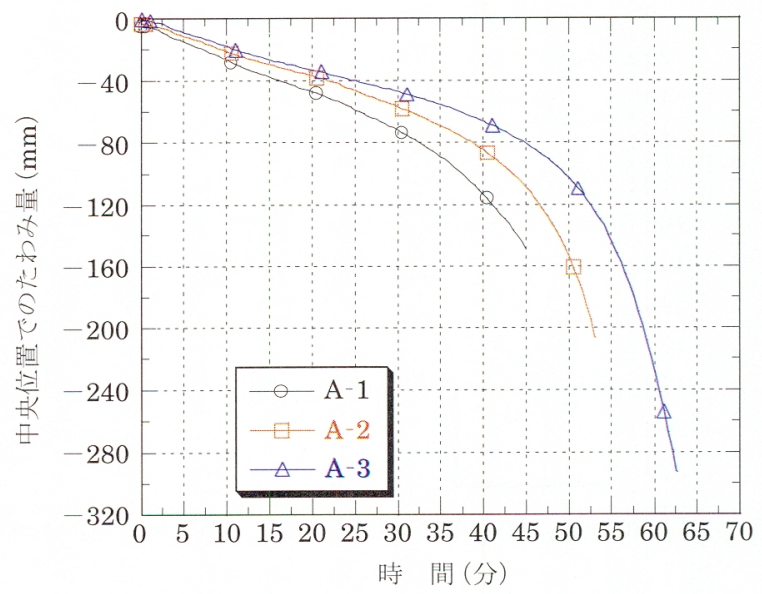

図-8中央位置たわみ量の経時変化 $(\mathrm{A}$ シリーズ $)$

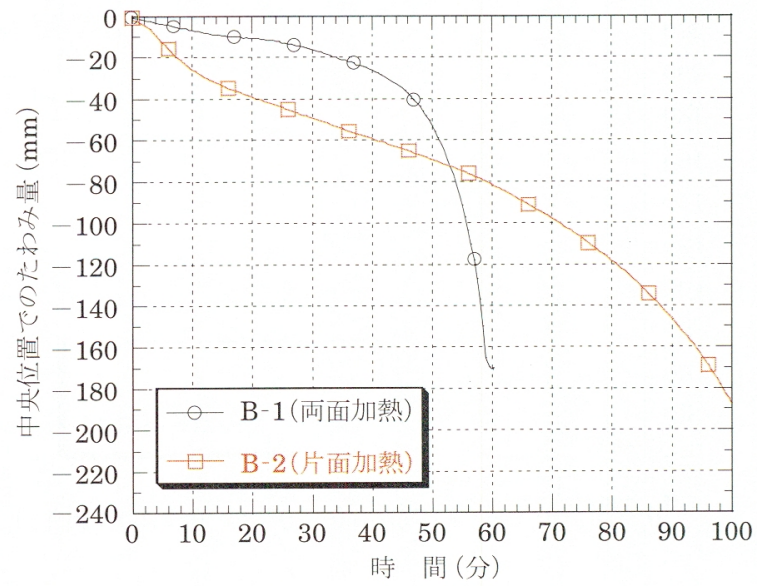

図-9 加熱方法による比較 
加熱試験体より早く高くなるため曲げ㴊性の低下が早く なり，加熱後55 分程度でたわみ量の逆転が起こった。 その後, 両面加熱では变形が急激に進行して崩壊に至り, 崩壊時のたわみ量は両面加熱の方が少なかった。

緊張力に関しては, 図-10に示すように，19本より $\mathrm{PC}$ 鋼線を使用して緊張力を大きくした B-4 試験体の方 がたわみ速度は速かった。こ机は，て本より PC 鋼線と 19 本より $\mathrm{PC}$ 鋼線による差と考えられ，19本より PC 鋼線では 19 本の鋼線が均等に荷重を負担していないた め上考えられる。

なお， B-3 抢よび B-4 試験体は，荷重支持能力を失う 前に実験の都合上，加熱後 72 分で加熱制御を終了した。

次に，スラブの遮熱性（試験体の裏面温度上昇が，平 均で $140 \mathrm{~K}$ 以下，最高で $180 \mathrm{~K}$ 以下であること）を確 認するため, 裏面温度を検討した。一例を図-11に示す。 裏面温度はリブ部（厚さ $250 \mathrm{~mm}$ および $170 \mathrm{~mm}$ ）およ び一般部 (70 mm) の非加熱面側において, 計 6 点に て計測を行った。B-2 試験体では平均温度扮よび最高温 度に関し，それぞれ 73 分および 64 分にて遮熱性を失っ た。B-3 および B-4 試験体においても，ほぼ同様の裏面 温度であった。

\section{5 火災時耐力の検討}

本節では, 高温時の曲げ而力の評価を行う。プレスト

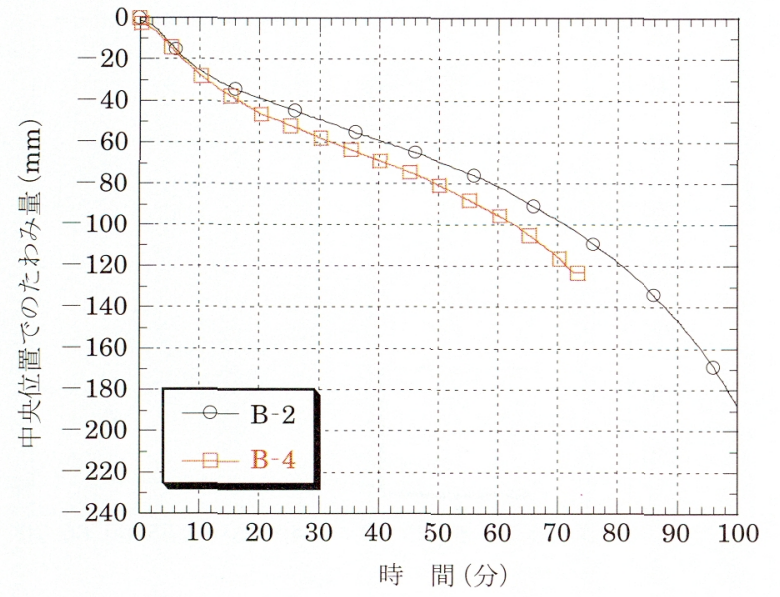

図-10 緊張力および緊張材仕様による比較

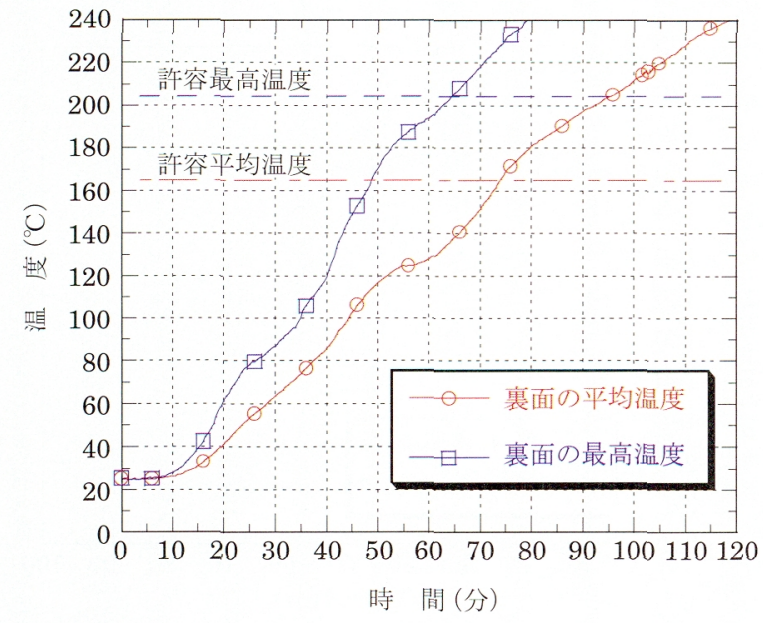

図-11 裏面最高および平均温度（B-2 試験体）
レスト構造での終局曲げ耐力はプレストレス導入力の大 きさには無関係であり, 引張鉄筋および緊張材の高温時 の降伏強度に依存すると考えられる。そこで下端引張を 受ける断面において, 以下の鉄筋コンクリート造梁の終 局曲げ強度式による高温時曲げ而力の検討を試みる。

$$
M u(t)=\Sigma 0.9 \times a_{t} \times \sigma_{y}(t) \times d
$$

ここで, $M u(t)$ : 温度 $t$ での曲げ而力, $a_{t}$ : 引張鉄筋 および緊張材の断面積, $\sigma_{y}(t)$ : 温度 $t$ での引張鉄筋お よび緊張材の降伏強度, $d$ : 圧縮縁から引張鉄筋掞よび 緊張材までの距離

以上より，引張鉄筋および緊張材の温度と引張鉄筋招 よび緊張材の高温時特性を評価することにより, 正曲げ 老受ける高温時の曲げ耐力の評価が可能となる。本実験 では単純梁であることから, 中央位置での高温時曲げ耐 力が作用モーメントに一致した時点が崩壊を意味するこ とになる9”。両端固定条件の場合には，例えば文献 9）に より両端部での高温時耐力も評価する必要がある。

想定した緊張材の高温時特性 ${ }^{10)}$ を図-12に，検討結果 の一例 (B-1 試験体) を図-13 に示す。使用した $\mathrm{PC}$ 鋼 より線温度は実験結果に基づいて評価した。高温時の曲 げ耐力は徐々に減少し，常温時に刘する高温時の曲げ耐 力が常温時での作用荷重 $(M / M u=0.27)$ となった時 点が予想耐火時間である。本手法による全試験体での検

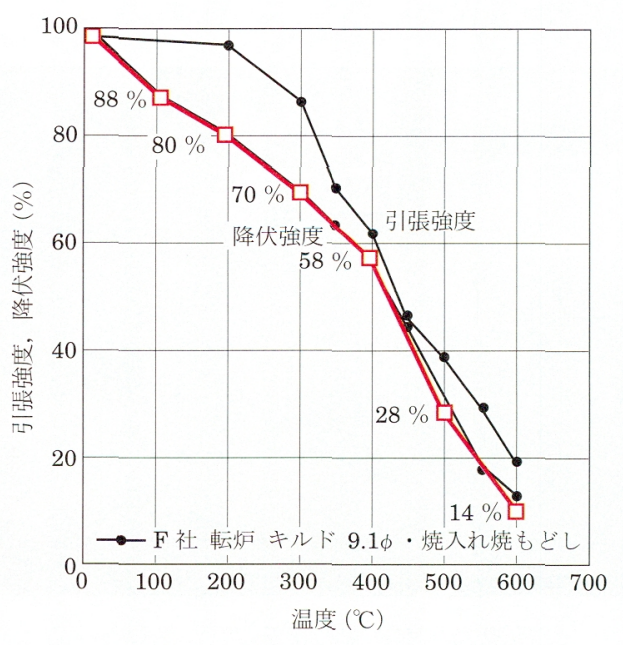

図-12 想定した緊張材の高温特性 ${ }^{10}$

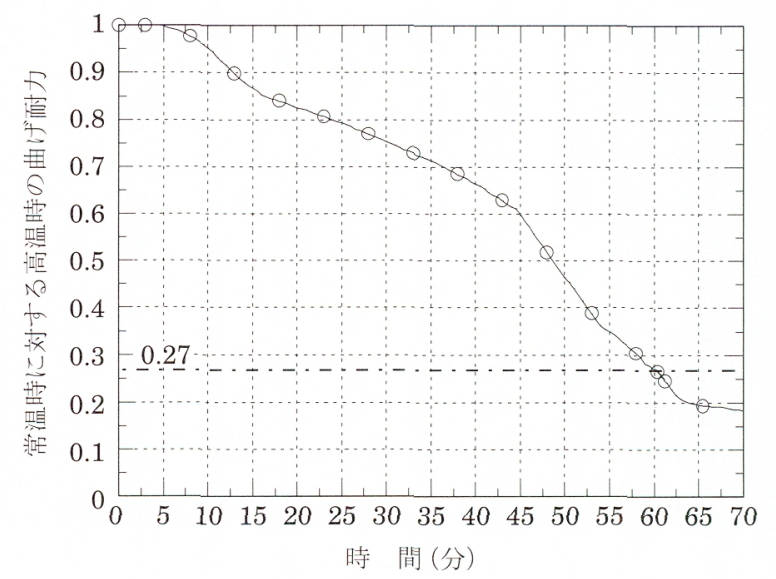

図-13 曲げ耐力の時間推移の一例（B-1 試験体） 
表-4 実験と予想耐火時間の比較（シリーズ A )

\begin{tabular}{c|c|c|c}
\hline 試験体 & $\begin{array}{c}\text { 実験桖火時間 } t_{r} \\
\text { (分) }\end{array}$ & $\begin{array}{c}\text { 予想耐火時間 } t_{p} \\
\text { (分) }\end{array}$ & $t_{p} / t_{r}$ \\
\hline A-1 & 45 & 46 & 1.02 \\
\hline A-2 & 53 & 49 & 0.92 \\
\hline A-3 & 60 & 52 & 0.87 \\
\hline
\end{tabular}

表-5 実験と予想耐火時間の比較（シリーズ B )

\begin{tabular}{c|c|c|c}
\hline 試験体 & $\begin{array}{c}\text { 実験耐火時間 } t_{r} \\
\text { (分) }\end{array}$ & $\begin{array}{c}\text { 予想耐火時間 } t_{p} \\
\text { (分) }\end{array}$ & $t_{p} / t_{r}$ \\
\hline B-1 & 56 & 60 & 1.07 \\
\hline B-2 & 100 & 83 & 0.83 \\
\hline
\end{tabular}

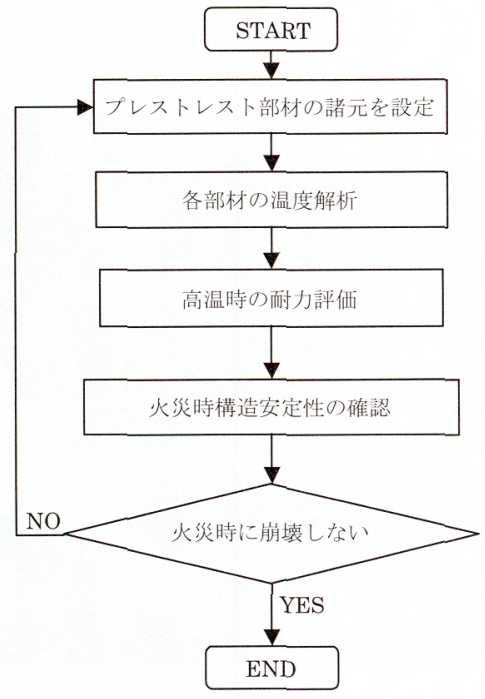

図-14 耐火設計フロー

討結果を表-4〜表-5 に示す。実験と解析での耐火時間 の比は 0.83〜1.07であり，良好な結果が得られた。

\section{6 耐火設計手法}

プレストレスト部材の耐火設計の一手法を図-14 に示 す。本手法により，プレストレスト部材の耐火設計が可 能になる。

(1)引張鋼材の温度履歴を熱伝導解析より評価する。

(2)引張鋼材の高温時強度を評価する。

(3)式（1）により，高温時曲げ而少力を評価する。

(4)力学的境界条件を考慮し，保有耐火時間を推定する。

(5)当該室の火災継続時間との比較を行い，下式を満足

することを確かめる。満足しない場合には，プレス

トレスト部材の諸元を再設定し，式（2）を満足す

るまで実施する。

$$
{ }_{p s} t_{f r}>t_{f}
$$

ここで, ${ }_{p s} t_{f r}$ ：プレストレス部材の保有耐火時間

$$
t_{f}: \text { 火災継続時間 }
$$

3. 実施適用

\section{1 建 物 概 要}

ここまで検討を行ったUFCを用いたプレストレスト スラブを大成建設(株技術センターリニューアル工事に適 用した。建物の外観を写真-5に，断面を図-15に示す。

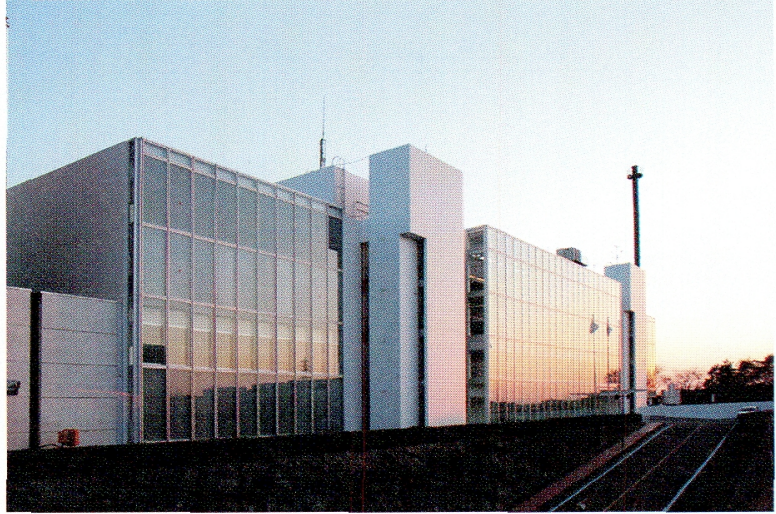

写真-5 大成建設技術センターの外観

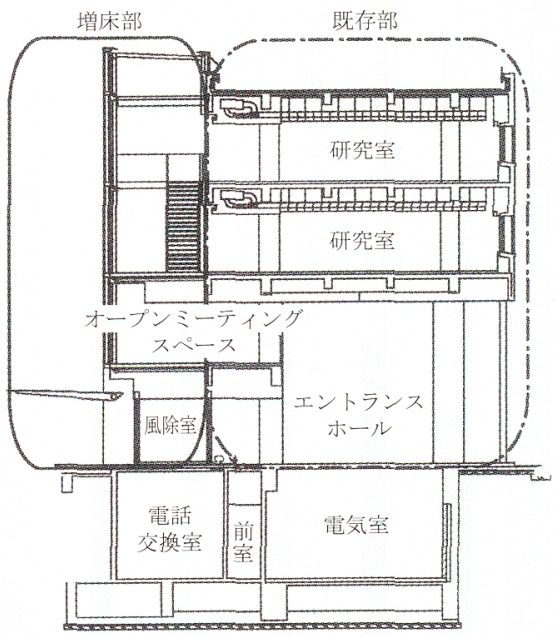

図-15大成建設技術センターの断面

本工事はリニューアル工事であり，UFC スラブを増 床部分に適用した。本 UFC スラブは，耐火性能之超高 強度を両立させることが可能であることから既存躯体の 負担を最小限に低減させることができるとともに，開放 的な空間を提供することが可能となった。

\subsection{UFC スラブの圧縮強度}

本報に扮けるUFCの適用物件は建築構造物であり， スラブの強度管理は実部材の構造体コンクリート強度を 基本として考えることになる。そこで，施工に先立ち， 図-16に示す実大模擬部材を製作し，部材の構造体コン クリート強度（コア強度）上，標準養生供試体および蒸 気養生供試体の圧縮強度の関係を調べることとした。各 供試体の強度試験結果を図-17 に示す。蒸気養生を行っ た後の材齢 14 日では，模擬部材はおおむねどの部分で も压縮強度 $200 \mathrm{~N} / \mathrm{mm}^{2}$ を得られることがわかる。また， 実際の構造体コンクリート強度より屯やや低い屯のの, 管理用の供試体として蒸気養生供試体を用いれば，部材 の強度管理は安全側に行えることがわかる。

\subsection{UFC スラブの製作・施工}

UFC スラブは,プレテンション方式にて製作した。UFC の打設では，打継ぎ面を作らないよう片側から一方向に 向かって実施した。また，差し棒で練り混ぜることによっ て，鋼繊維の偏り防止，界面の防止安実施した（写真-6）。 

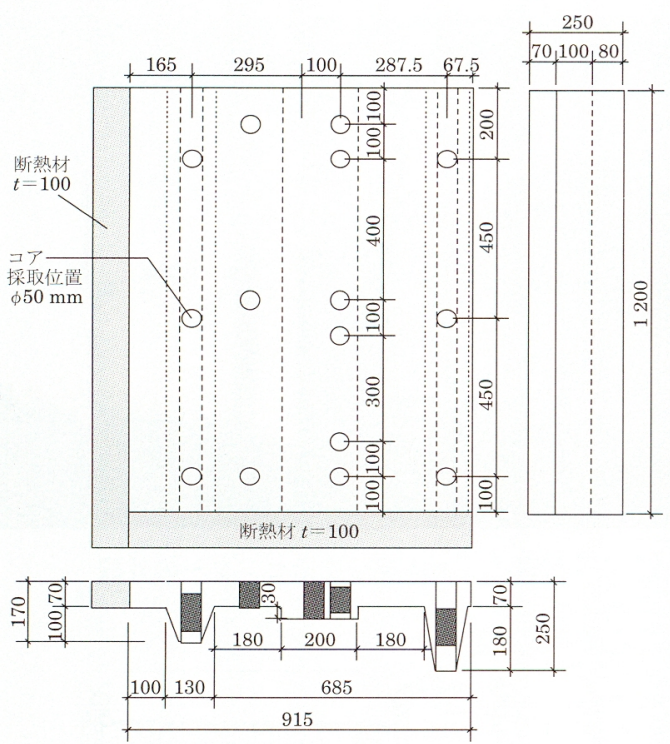

図-16＼cjkstart構造体コンクリート

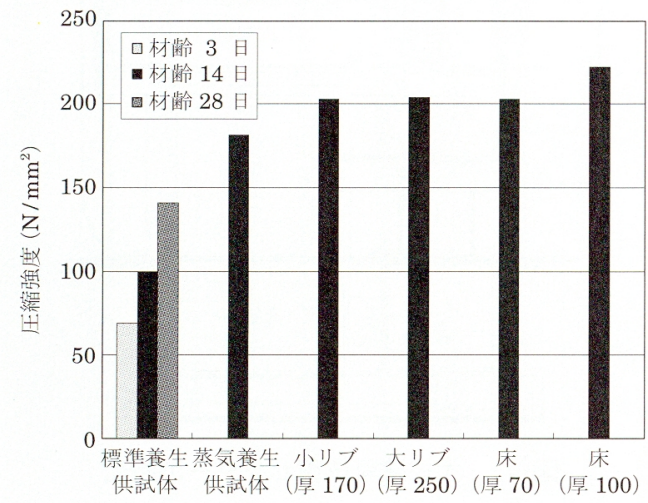

図-17 供試体とコア強度の比較

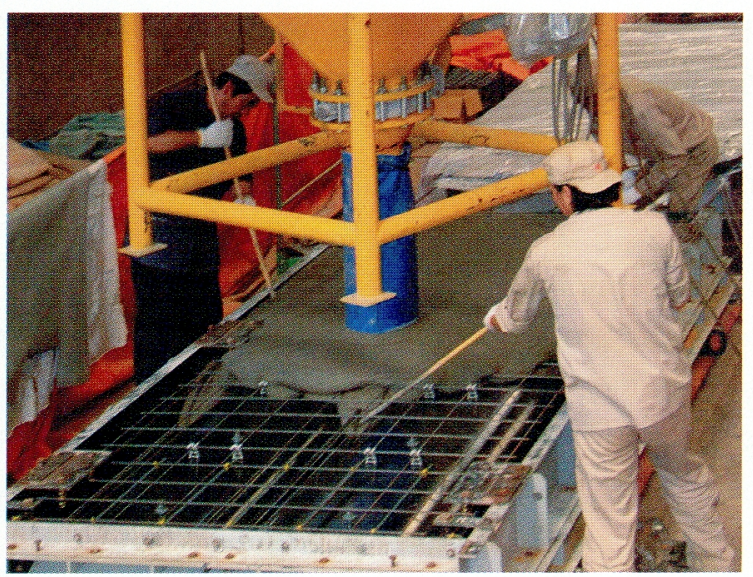

写真-6 打設状況

常温での 1 次養生を終了した $\mathrm{UFC}$ は $90^{\circ} \mathrm{C}$ の蒸気養生 を 48 時間行った。製品之同一養生供試体での, 蒸気養 生後の厈縮強度の分布を図-18 に示す。サンプル数は 14 であり, 平均で $171 \mathrm{~N} / \mathrm{mm}^{2}$, 最大值 $183 \mathrm{~N} / \mathrm{mm}^{2}$, 最小 值 $154 \mathrm{~N} / \mathrm{mm}^{2}$ ，標準偏差 $8.6 \mathrm{~N} / \mathrm{mm}^{2}$ であった。

UFC スラブの取り付け状況を写真-7 に示す。新規鉄 骨柱側はスラブ端部に山した鋼材と受け鉄骨梁を直接ボ ルト接合し，既存躯体側は既存梁にアンカーを施して緊 結した。設置完了状況を写真-8に示す。UFC 老用いた

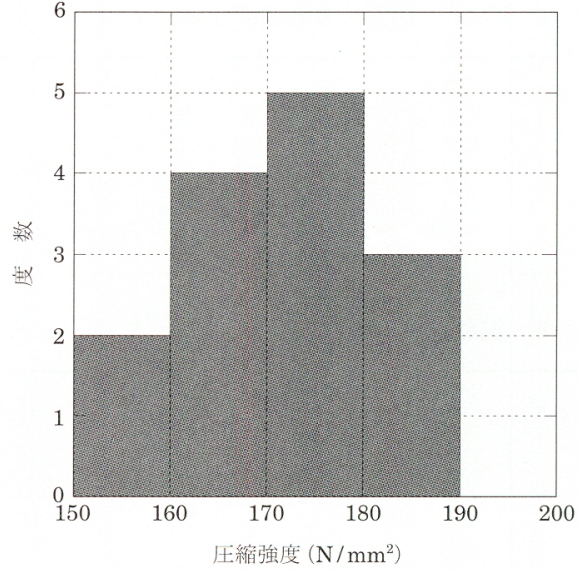

図-18 圧縮強度の分布

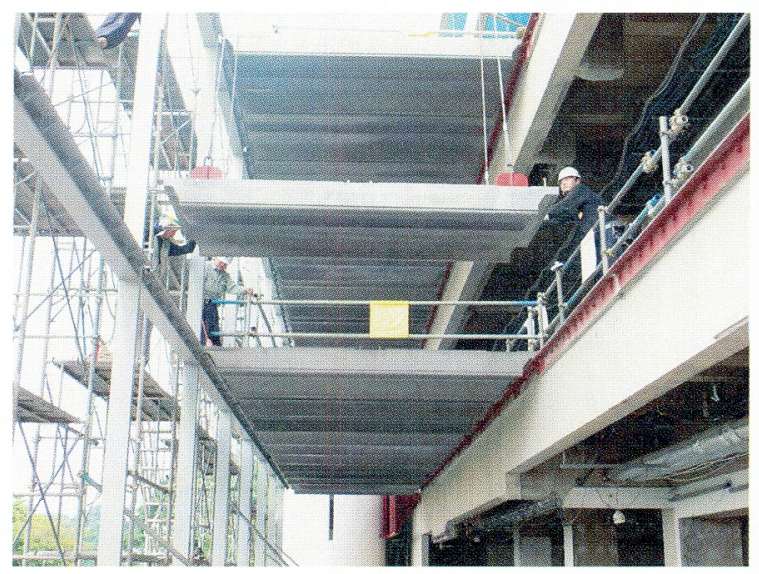

写真-7 取り付け状況

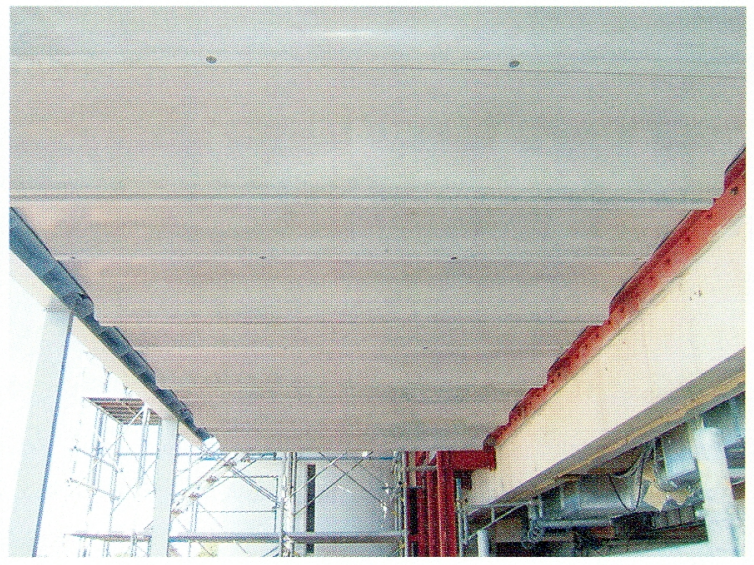

写真-8 設置完了状況

プレキャストプレストレストスラブとすることで，連続 生産ができることから工期の短縮, また高品質材料の提 供を実現できた。

\section{4. ま 々}

本報では，UFCの材料特性掞よびプレストレスト部 材の耐火性能を明らかにすることができた。さらに，載 荷加熱試験により高温時の曲げ而力を評価することが可 能となったことから，プレストレスト部材の耐火設計手 法の提案老行うことができた。 
今後，さらなる解析による検討を実施し，プレストレ スト部材の耐火性能を検討する予定である。

\section{参 考 文 献}

1）土木学会：超高強度繊維補強コンクリートの設計・・施工指針（案）， 2004. 10

2）武者浩透 - 大熊 光 - 大竹明朗 - 児玉明彦 - 関 文夫 - 小林忠司： 無機系複合材料（RPC）を用いた酒田みらい橋の設計と施工，橋 梁之基礎，Vol.42, No.10, pp.2 11, 2002.11

3）萱嶋 誠・篠崎洋三・飯塚崇文・大和矢麻紀：Fc $200 \mathrm{~N} / \mathrm{mm}^{2}$ 級 の超高強度繊維補強コンクリートを用いた連絡橋の設計・施工, コンクリート工学, Vol.43, No.7, pp.65〜69, 2005.7

4）日本建築学会：建築工事標準仕様書・同解説 JASS 5 鉄筋コン クリート工事, 1997
5）阂藤 光：プレストレスコンクリート部材の爆裂について，日本 火災学会論文集, Vol.15, No.2, pp.23〜30, 1966

6）日本建築学会：プレストレストコンクリート設計施工規準・同解 説，2005. 1

7）西山峰広・原田和典・谷 昌典：プレストレストコンクリート梁 部材の高温時曲げ耐力評価, 日本建築学会構造系論文集, No.606, pp.171 178, 2006.8

8) ISO/FDIS $834-1$ : Fire-resistance tests - Elements of building construction--, Part 1 General requirements, 1999

9）国土交通省住宅局：耐火性能検証の解説及び計算例とその解説, 2001.3

10）日本鋼構造協会：鉄筋コンクリート用棒鋼および $\mathrm{PC}$ 鋼棒・鋼線 の高温時ならびに加熱後の機械的性質, JSSC, Vol.5, No.45, pp.1 62, 1969

\section{コンクリートの凍結融解抵抗性の評価方法に関する シンポジゥム 論文集}

JCI では平成 18 年度から「コンクリートの凍結融解抵抗性の評価方法に関する研究委員会」を設置し，コンクリートの耐凍 害性を適切かつ簡易に評価できる手法の検討を主目的に活動を開始して扔ります。今回委員会活動の一環として, 最新の研究成 果を集めること，既往の研究成果の集約を図ること，関連の研究者間の情報交換の場を設けること，などを目的にシンポジウム を開催しました。本書は 2006 年 12 月 6 日に開催されました「コンクリートの凍結融解抵抗性の評価方法に関するシンポジゥム」 において発表された論文を収録したものです。

1. 水力発電設備の凍害被害状況について

成田＼cjkstart健（東北電力）

2. 凍害に対する地域条件評価指標の検討

長谷川拓哉 (北海道大学)

3. 寒冷地における海洋コンクリートのスケーリングに関する研究 加藤利菜 (北見工業大学)

4.コンクリートのスケーリングに扔ける蓄積された融雪剤の希釈的な特性と劣化の数量的考察

5. スケーリング劣化抵抗性の予測・判定手法の一提案

6. 限界飽水度法を用いたコンクリートの耐凍害性評価

7. 各種減水剂を用いた $\mathrm{AE} コ$ コクリートの涷結融解抵抗性

8. ポゾラン高含有セメントを用いたコンクリートの凍結融解抵抗性に関する一考察

9. 高吸水率細・粗骨材の使用がコンクリートの凍結融解抵抗性に及ぼす影響

10. 表層部緻密化コンクリートの凍結融解抵抗性に関する実験的研究

11. 超音波法によるコンクリート製水路の凍害診断

12. 超音波伝播速度測定による寒コンクリート構造物の凍害深さ推定について

13. 凍害劣化深さを指標としたコンクリートの耐久性評価

14. 凍害によるスケーリングの評価方法に関する一考察

15. 凍結融解試験法の違いによる塩化物作用下でのコンクリートの耐凍害性評価

16. コンクリートの凍結融解試験方法の合理化に関する検討

17. 凍結融解試験に打ける測定方法の相違が試験結果に及ぼす影響

18. 骨材の簡易凍結融解試験法の検討

高科 豊（神戸市立工業高専） 遠藤裕丈（土木研究所） 千歩 修 (北海道大学) 近松竜一 (大林組) 桜井邦昭 (大林組) 麓隆行 (近畿大学) 菅原 隆 (八戸工業高専) 緒方英彦（鳥取大学） 林田宏（土木研究所） 阿波 稔 (八戸工業大学) 添田政司（福岡大学） 権代由範（八戸工業大学） 伊藤純平（横浜理化） 近松竜一 (大林組) 片平 博 (土木研究所)

A 4 判・110 ページ（2006 年刊行）／定価 4200 円（税込）, 会員特価 3780 円（税込）／送料 340 円

- 申込先：(社)日本コンクリート工学協会「書籍販売」係

テ102-0083 東京都千代田区麹町 1-7 相互半蔵門ビル 12 階／電話（03）3263-1573 